\title{
Foreign Language Vocabulary Learning Strategies in Malaysia
}

\author{
Zaid Arafat Mohd Noor¹, Nik Mohd Rahimi Nik Yusoff², Irma Martiny Md. Yasim¹, \\ Mohd Yusri Kamarudin ${ }^{1}$ \\ ${ }^{1}$ Ministry of Education, Putrajaya, Malaysia \\ ${ }^{2}$ Faculty of Education, National University of Malaysia, Bangi, Malaysia \\ Email: zaid.noor@moe.gov.my, nik@ukm.edu.my, irmamartiny@yahoo.com, yusriqanun@yahoo.com
}

Received 1 February 2016; accepted 13 March 2016; published 16 March 2016

Copyright (C) 2016 by authors and Scientific Research Publishing Inc.

This work is licensed under the Creative Commons Attribution International License (CC BY). http://creativecommons.org/licenses/by/4.0/

\section{(c) (i) Open Access}

\section{Abstract}

Arabic Language is a compulsory subject for students in National Religious Secondary School (SMKA) in Malaysia. Therefore, students need to increase Arabic vocabulary to master their language skills. This study aims to identify the level of Arabic Vocabulary Learning Strategies applied by students and to identify the level of the Arabic Vocabulary Mastery by students of National Religious Secondary School (SMKA). The study used questionnaire and a written test as an instrument of data collection. The sample of study consisted of 157 Form Four students randomly chosen from Secondary School in Malaysia. The results showed that the level of Arabic Vocabulary Learning Strategies applied by students and the level of the Arabic Vocabulary Mastery by students at Secondary School in Malaysia were at moderate level. Pedagogical implications of this study is that effective Vocabulary Learning Strategies should be exposed to the students in the learning process, so that students can use various Vocabulary Learning Strategies to enhance their Arabic Vocabulary Mastery.

\section{Keywords}

Language Learning Strategies, Vocabulary, Foreign Language and Arabic Languages

\section{Introduction}

Recognizing the importance of mastering a foreign language in education, the schools in Malaysia are encouraged to offer a foreign language for their students. For religious based school like National Religious Secondary School (SMKA), Arabic has become a compulsory foreign language subject. The mastery of vocabulary is important in order to enhance foreign language skills as set by the Ministry of Education. Vocabulary can be de- 
fined as a set of words to speak and write which contain meaning and are understood by the speakers of the language (Susanti, 2002; Yusoff, Ghani, \& Al-Qusyairi, 2008). The language students are not able to communicate and convey the message clearly might be caused by lack of vocabulary (Daud \& Pisal, 2014; Gan, 2012). One of the factors that distinguish the level of foreign language achievement of a student is Language Learning Strategy (LLS) used. The studies about LLS in Malaysia have found a significant relationship between the use of LLS with skills and mastery of the language (Baharudin \& Ismail, 2014; Nurazan, 2004; Teh, Yusoff, Embi, \& Mahamod, 2000). The study done by Mahamod \& Embi (2005) which focuses on the use of Language Learning Strategy among brilliant students and weak students in mastering English Language reading finds that the excellent students use more LLS in order to enhance their language skills compared to weak students. Similarly, the study done by Mahamod, Embi, \& Yusoff (2010) finds that student who masters the language skills namely reading, writing, listening and speaking skills uses various LLS. The studies about Arabic Language Learning Strategy conducted by Embi, Long, \& Hamzah (2001), Nurazan (2004), KamarulShukri (2009) and Yasim (2012) also show that excellent students tend to use more LLS in learning the language.

\section{Research Methods}

This study aims to look at Language Learning Strategy (LLS) which focuses on vocabulary component in foreign language offered as a subject at secondary school level. The objectives of the study are as follows: a) to identify the level of Arabic Vocabulary Learning Strategies (AVLS) is applied by students in Secondary School (SMKA) in Malaysia; and b) to identify the level of vocabulary mastery of National Religious Secondary School (SMKA) students.

This study was conducted in two selected National Religious Secondary Schools (SMKA) in Malacca. The schools were randomly selected for their excellent achievement in the Lower Secondary Examination (PMR) in Arabic Language Subject in the country. A total number of 157 samples from Form Four students were randomly selected to be the representative National Religious Secondary School (SMKA). This study is conducted by using a survey which comprises of a questionnaire as an instrument for data gathering about the level of Arabic Vocabulary Learning Strategies (AVLS). Based on the samples and written tests collected, they help to determine the level of the students' Arabic Vocabulary Mastery.

The questionnaire consists of: a) Arabic Vocabulary Learning Strategies (AVLS) questionnaire, which is modified from Mahamod et al. (2010) Language Learning Strategies questionnaires. AVLS questionnaire used Likert 5-point scale to measure learning strategies applied by the students. b) Vocabulary Written Test (VWT) which is used to examine the level of vocabulary mastery among the sample of study. The test was developed by using the Arabic Vocabulary that has been listed by the Ministry of Education (MOE) in the Arabic Language Syllabus (ALS). The test consists of 57 selected Arabic words from the list after a difficulty test and experts review. The reliability of this instrument is at the highest level where the value of Alpha Cronbach is 0.83 .

Descriptive statistics are used to describe the information about Arabic Vocabulary Learning Strategies (AVLS) used by the students in Classroom (VLSC), outside the class (VLSO) and during the examination period (VLCE). The statistics used are frequency, percentage, mean, and standard deviation. Horwitz \& Oxford (1991) interpretation of score is adapted to interpret the AVLS applied by sample of study as shown in Table 1.

The total score of Vocabulary Written Test (VWT) for every sample of study was divided into 5 levels of achievements as shown in Table 2.

\section{Result and Discussion}

\subsection{What Are the Level of Arabic Vocabulary Learning Strategies Applied by National Religious Secondary School (SMKA) Students?}

The discussions on the use of Arabic DSS applied by the students are explained separately i.e. whether Arabic Vocabulary Learning Strategies are used by the students in the Classroom (VLSC), outside Classroom (VLSO) and during examination period (VLCE).

a) Arabic Vocabulary Learning Strategies in Classroom (VLSC)

The results (Table 3 ) show that $37.5 \%$ of items (3 out of 8 strategies) consist of B9, B10 and B14 are at moderate to high level. A total of $62.5 \%$ of items (5 out of 8 strategies) consist of B7, B8, B11, B12, B13 and B14 
Table 1. Mean score interpretation of vocabulary learning strategies).

\begin{tabular}{ccc}
\hline Mean Scores & Interpretation \\
\hline $1.0-1.4$ & Low \\
$1.5-2.4$ & Medium Low \\
$2.5-3.4$ & Medium \\
$3.5-4.4$ & Medium High \\
$4.5-5.00$ & Height \\
\hline
\end{tabular}

Table 2. Written test achievement scores.

\begin{tabular}{cccc}
\hline Level & Score & Percent (\%) & Interpretation \\
\hline 1 & $0-11$ & $0-19$ & Very poor \\
2 & $12-23$ & $20-39$ & Weak \\
3 & $24-35$ & $40-49$ & Moderate \\
4 & $36-47$ & $50-69$ & Good \\
5 & $48-57$ & $79-100$ & Excellent \\
\hline
\end{tabular}

Table 3. Frequency, percentage, mean and standard deviation for Arabic Vocabulary Learning Strategies in Classroom (VLSC).

\begin{tabular}{|c|c|c|c|c|c|c|c|c|}
\hline $\begin{array}{l}\text { Vocabulary Learning } \\
\text { Strategies }\end{array}$ & $\begin{array}{l}\text { Strongly } \\
\text { Not Agree } \\
\text { (N) } \%\end{array}$ & $\begin{array}{l}\text { Do Not } \\
\text { Agree } \\
\text { (N) } \%\end{array}$ & $\begin{array}{l}\text { Somewhat } \\
\text { Agree } \\
\text { (N) \% }\end{array}$ & $\begin{array}{l}\text { Agree } \\
(\mathrm{N}) \%\end{array}$ & $\begin{array}{l}\text { Strongly } \\
\text { Agree } \\
\text { (N) \% }\end{array}$ & Mean & $\begin{array}{l}\text { Standard } \\
\text { Deviation }\end{array}$ & Mean Interpretation \\
\hline $\begin{array}{l}\text { [B7] I revise Arabic vocabulary } \\
\text { learning before the class starts. }\end{array}$ & $\begin{array}{l}(21) \\
13.4\end{array}$ & $\begin{array}{l}(41) \\
26.1\end{array}$ & $\begin{array}{l}(71) \\
45.2\end{array}$ & $\begin{array}{l}(22) \\
14.0\end{array}$ & $\begin{array}{l}(2) \\
1.3\end{array}$ & 2.64 & 0.928 & Low \\
\hline $\begin{array}{l}\text { [B8] I do Arabic vocabulary exercise } \\
\text { before the class starts. }\end{array}$ & $\begin{array}{l}(23) \\
14.6\end{array}$ & $\begin{array}{l}(54) \\
34.4\end{array}$ & $\begin{array}{l}(60) \\
38.2\end{array}$ & $\begin{array}{l}(19) \\
12.1\end{array}$ & $\begin{array}{l}(1) \\
0.6\end{array}$ & $2: 50$ & 0.910 & Low \\
\hline $\begin{array}{l}\text { [B9] I ask the teacher if I do not } \\
\text { understand the meaning of a word. }\end{array}$ & $\begin{array}{l}(5) \\
3.2\end{array}$ & $\begin{array}{l}(16) \\
10.2\end{array}$ & $\begin{array}{l}(41) \\
26.2\end{array}$ & $\begin{array}{l}(61) \\
38.9\end{array}$ & $\begin{array}{l}(34) \\
21.7\end{array}$ & 3.66 & 1.03 & Medium High \\
\hline $\begin{array}{l}\text { [B10] I ask a friend if I do not } \\
\text { understand the meaning of a word. }\end{array}$ & $\begin{array}{l}(4) \\
2.5\end{array}$ & $\begin{array}{l}(7) \\
4.5\end{array}$ & $\begin{array}{l}(23) \\
14.6\end{array}$ & $\begin{array}{l}(77) \\
49.0\end{array}$ & $\begin{array}{l}(46) \\
29.3\end{array}$ & 3.98 & 0.923 & Medium High \\
\hline $\begin{array}{l}\text { [B11] I'm fully focused while } \\
\text { learning Arabic vocabulary. }\end{array}$ & $\begin{array}{l}(2) \\
1.3\end{array}$ & $\begin{array}{l}(16) \\
10.2\end{array}$ & $\begin{array}{l}(65) \\
41.4\end{array}$ & $\begin{array}{l}(54) \\
34.4\end{array}$ & $\begin{array}{l}(20) \\
12.7\end{array}$ & $3: 47$ & 0.888 & Low \\
\hline $\begin{array}{l}\text { [B12] I ask the teacher to amend my } \\
\text { Arabic vocabulary. }\end{array}$ & $\begin{array}{l}(11) \\
7.0\end{array}$ & $\begin{array}{l}(19) \\
12.1\end{array}$ & $\begin{array}{l}(61) \\
38.9\end{array}$ & $\begin{array}{l}(55) \\
35.0\end{array}$ & $\begin{array}{c}(11) \\
7.0\end{array}$ & 3.23 & 0.993 & Low \\
\hline $\begin{array}{l}\text { [B13] I am actively involved in } \\
\text { learning Arabic vocabulary. }\end{array}$ & $\begin{array}{l}(12) \\
7.6\end{array}$ & $\begin{array}{l}(25) \\
15.9\end{array}$ & $\begin{array}{l}(71) \\
45.2\end{array}$ & $\begin{array}{l}(40) \\
25.5\end{array}$ & $\begin{array}{l}(9) \\
5.7\end{array}$ & 3.06 & 0.976 & Low \\
\hline $\begin{array}{l}\text { [B14] I refer to the dictionary to } \\
\text { understand the meaning of a } \\
\text { vocabulary in Arabic. }\end{array}$ & $\begin{array}{c}(10) \\
6.4\end{array}$ & $\begin{array}{l}(19) \\
12.1\end{array}$ & $\begin{array}{l}(42) \\
26.8\end{array}$ & $\begin{array}{l}(49) \\
31.2\end{array}$ & $\begin{array}{l}(37) \\
23.6\end{array}$ & 3.54 & 1.63 & Medium High \\
\hline
\end{tabular}

are at moderate level.

The level of Arabic Vocabulary Learning Strategies in Classroom (VLSC) is at a medium level (mean 3.3). The result shows that the students depend on their friends and teachers or they refer to the dictionary to solve the problems if they do not understand the vocabulary. The students also do not do enough revision, reinforcement, exercises or self-access learning to learn Arabic vocabulary before the class starts. Thus, it can be concluded that the strategies that can be used by the students to master the Arabic vocabulary are:

i) To have an interest in learning Arabic vocabulary. 
ii) To ask a friend if they do not understand the vocabulary.

iii) To let the students to explain to one another about the meaning of incomprehensible vocabulary.

iv) To refer to the dictionary to understand Arabic vocabulary.

b) Arabic Vocabulary Learning Strategies outside the Classroom (VLSO)

The results (Table 4 ) show that only $7.7 \%$ of items (1 out of 13 strategies) of C24 are at moderately high level of usage. A total of $69.2 \%$ of items (9 out of 13 strategies) of C16, C19, C20, C21, C22, C23, C25, C26 and C27 are at moderate level. A total of $23.1 \%$ of items (3 out of 13 strategies) of C15, C17 and C18 are at moderate to low. The item that is at moderately high level is C24, i.e. I asked a friend if I do not understand something in Arabic vocabulary.

The findings show that the students are more dependent on their peers to enhance their Arabic vocabulary in the classroom. The students are less dependent on the teacher and dislike to refer to the dictionary outside of the class. The students also do not do enough vocabulary exercises or try to find relevant materials to be used as Arabic vocabulary exercise materials outside the classroom.

The level of Arabic Vocabulary Learning Strategies outside Classroom (VLSO) is at a medium level (mean

Table 4. Frequency, percentage, mean and standard deviation for Arabic Vocabulary Learning Strategies outside Classroom (VLSO).

\begin{tabular}{|c|c|c|c|c|c|c|c|c|}
\hline Vocabulary Learning Strategies & $\begin{array}{l}\text { Strongly } \\
\text { Not Agree } \\
\text { (N) } \%\end{array}$ & $\begin{array}{l}\text { Do Not } \\
\text { Agree } \\
\text { (N) } \%\end{array}$ & $\begin{array}{l}\text { Somewhat } \\
\text { Agree } \\
\text { (N) } \%\end{array}$ & $\begin{array}{l}\text { Agree } \\
(\mathrm{N}) \%\end{array}$ & $\begin{array}{l}\text { Strongly } \\
\text { Agree } \\
\text { (N) \% }\end{array}$ & Mean & $\begin{array}{c}\text { Standard } \\
\text { Deviation }\end{array}$ & Interpretation \\
\hline $\begin{array}{l}\text { [C15] I do a lot of Arabic vocabulary } \\
\text { exercises outside the classroom. }\end{array}$ & $\begin{array}{l}(28) \\
17.8\end{array}$ & $\begin{array}{l}(49) \\
31.2\end{array}$ & $\begin{array}{l}(62) \\
39.5\end{array}$ & $\begin{array}{l}(16) \\
10.2\end{array}$ & $\begin{array}{l}(2) \\
1.3\end{array}$ & $2: 46$ & 0.944 & Medium Low \\
\hline $\begin{array}{l}\text { [C16] I do Arabic vocabulary exercises } \\
\text { given by the teacher immediately. }\end{array}$ & $\begin{array}{l}(8) \\
5.1\end{array}$ & $\begin{array}{l}(29) \\
18.5\end{array}$ & $\begin{array}{l}(68) \\
43.3\end{array}$ & $\begin{array}{l}(41) \\
26.1\end{array}$ & $\begin{array}{c}(11) \\
7.0\end{array}$ & 3.11 & 0.961 & Medium \\
\hline $\begin{array}{l}\text { [C17] I do the vocabulary exercises in } \\
\text { Arabic even though the teacher does not } \\
\text { ask me to do. }\end{array}$ & $\begin{array}{l}(37) \\
23.6\end{array}$ & $\begin{array}{l}(58) \\
36.9\end{array}$ & $\begin{array}{l}(48) \\
30.6\end{array}$ & $\begin{array}{c}(10) \\
6.4\end{array}$ & $\begin{array}{l}(4) \\
2.5\end{array}$ & 2.27 & 0.978 & Medium Low \\
\hline $\begin{array}{l}\text { [C18] I look for substance-related } \\
\text { vocabulary in Arabic on the Internet for } \\
\text { extra exercises. }\end{array}$ & $\begin{array}{l}(43) \\
27.4\end{array}$ & $\begin{array}{l}(60) \\
38.2\end{array}$ & $\begin{array}{l}(43) \\
27.4\end{array}$ & $\begin{array}{l}(8) \\
5.1\end{array}$ & $\begin{array}{l}(3) \\
1.9\end{array}$ & 2.16 & 0.951 & Medium Low \\
\hline $\begin{array}{l}\text { [C19] I ask the teacher to check the answer } \\
\text { or comment on the Arabic vocabulary } \\
\text { exercises that I have done. }\end{array}$ & $\begin{array}{l}(16) \\
10.2\end{array}$ & $\begin{array}{l}(45) \\
28.7\end{array}$ & $\begin{array}{l}(59) \\
37.6\end{array}$ & $\begin{array}{l}(33) \\
21.0\end{array}$ & $\begin{array}{l}(4) \\
2.5\end{array}$ & 2.77 & 0.980 & Low \\
\hline $\begin{array}{c}\text { [C20] I record the difficult Arabic } \\
\text { vocabulary that I found when reading } \\
\text { Arabic materials. }\end{array}$ & $\begin{array}{l}(9) \\
5.7\end{array}$ & $\begin{array}{l}(30) \\
19.1\end{array}$ & $\begin{array}{l}(51) \\
32.5\end{array}$ & $\begin{array}{l}(45) \\
28.7\end{array}$ & $\begin{array}{l}(22) \\
14.0\end{array}$ & 3.26 & 1099 & Low \\
\hline $\begin{array}{l}\text { [C21] I use new Arabic vocabulary in my } \\
\text { writing. }\end{array}$ & $\begin{array}{c}(10) \\
6.4\end{array}$ & $\begin{array}{l}(33) \\
21.0\end{array}$ & $\begin{array}{l}(53) \\
33.8\end{array}$ & $\begin{array}{l}(46) \\
29.3\end{array}$ & $\begin{array}{c}(15) \\
9.6\end{array}$ & 3.15 & 1.061 & Low \\
\hline $\begin{array}{l}\text { [C22] I do a lot of revision on Arabic } \\
\text { vocabulary. }\end{array}$ & $\begin{array}{l}(19) \\
12.1\end{array}$ & $\begin{array}{l}(46) \\
29.3\end{array}$ & $\begin{array}{l}(59) \\
37.6\end{array}$ & $\begin{array}{l}(28) \\
17.8\end{array}$ & $\begin{array}{l}(5) \\
3.2\end{array}$ & 2.71 & 1.002 & Low \\
\hline $\begin{array}{c}\text { [C23] I ask my family/parents for help if I } \\
\text { do not understand the meaning of an } \\
\text { Arabic word. }\end{array}$ & $\begin{array}{l}(40) \\
25.5\end{array}$ & $\begin{array}{l}(37) \\
23.6\end{array}$ & $\begin{array}{l}(49) \\
31.2\end{array}$ & $\begin{array}{l}(23) \\
14.6\end{array}$ & $\begin{array}{l}(8) \\
5.1\end{array}$ & 2.50 & 1.169 & Low \\
\hline $\begin{array}{l}\text { [C24] I ask a friend if I do not understand } \\
\text { any Arabic vocabulary. }\end{array}$ & $\begin{array}{l}(6) \\
3.8\end{array}$ & $\begin{array}{l}(9) \\
5.7\end{array}$ & $\begin{array}{l}(38) \\
24.2\end{array}$ & $\begin{array}{l}(60) \\
38.2\end{array}$ & $\begin{array}{l}(44) \\
28.0\end{array}$ & 3.81 & 1.032 & Medium High \\
\hline $\begin{array}{l}\text { [C25] I ask the teachers in the staff } \\
\text { room/outside the classroom if I do not } \\
\text { understand the meaning of Arabic words. }\end{array}$ & $\begin{array}{l}(25) \\
15.9\end{array}$ & $\begin{array}{l}(36) \\
22.9\end{array}$ & $\begin{array}{l}(66) \\
42.0\end{array}$ & $\begin{array}{l}(24) \\
15.3\end{array}$ & $\begin{array}{l}(6) \\
3.8\end{array}$ & 2.68 & 1.038 & Low \\
\hline $\begin{array}{l}\text { [C26] I refer to the dictionary to } \\
\text { understand difficult vocabulary. }\end{array}$ & $\begin{array}{c}(14) \\
8.9\end{array}$ & $\begin{array}{l}(19) \\
12.1\end{array}$ & $\begin{array}{l}(53) \\
33.8\end{array}$ & $\begin{array}{l}(39) \\
24.8\end{array}$ & $\begin{array}{l}(32) \\
20.4\end{array}$ & $3: 36$ & 1.193 & Low \\
\hline $\begin{array}{c}\text { [C27] I read a lot of reading materials in } \\
\text { Arabic to help me master a wide range of } \\
\text { vocabulary. }\end{array}$ & $\begin{array}{c}(12) \\
7.6\end{array}$ & $\begin{array}{l}(31) \\
19.7\end{array}$ & $\begin{array}{l}(50) \\
31.8\end{array}$ & $\begin{array}{l}(34) \\
21.7\end{array}$ & $\begin{array}{l}(30) \\
19.1\end{array}$ & 3.25 & 1.196 & Low \\
\hline
\end{tabular}


2.9). Thus, it can be concluded that the strategies that can be used for students to master the Arabic vocabulary outside the classroom are:

i) To ask a friend if they do not understand the vocabulary.

ii) To refer to a dictionary to understand difficult vocabulary in Arabic.

iii) To read a variety of Arabic literature/reading materials that can help to gain a wide range of Arabic vocabulary.

c) Arabic Vocabulary Learning Strategies during the Examination Period (VLCE)

According to Table 5, the study finds that $20.0 \%$ of items (1 out of 5 strategies) of D29 is moderate to high. A total of $80.0 \%$ of items (4 out of the 5 strategies), the D28, D30, D31 and D32 are at a moderate level.

The findings show that the students depend on their friends if they do not understand the vocabulary. The students also memorize Arabic vocabulary as a preparation before sitting for the examination. The students also do very little revision on Arabic vocabulary especially on the questions that have come out in the exam. As a result, the students could not master the Arabic vocabulary by not being able to use a wide range of vocabulary when answering the exam questions.

The level of Arabic Vocabulary Learning Strategies during the examination period in the medium level (mean 3.2). Thus, it can be concluded that the strategies that could be used by the students to master the vocabulary in Arabic during the exam are:

i) To memorize difficult Arabic vocabulary before the examination.

ii) To discuss with their friends about past Arabic vocabulary questions that have come out in the exam.

\subsection{What Are the Level of Vocabulary Mastery of National Religious Secondary School (SMKA) Student?}

These are the findings for the overall Arabic Language written test scores among the Form Four students in SMKAs in Malacca. A total of 23 samples (14.6\%) are at an excellent level, a total of 34 samples (21.7\%) are at a good level, a total of 44 samples (28.0\%) are moderate, a total of 17 samples (10.8\%) are at a weak level, and a total of 39 samples (24.8\%) are at a very weak level. A total of $64.4 \%$ of students are in moderate, good and excellent level and only $35.6 \%$ of students are at poor and very poor level. This finding indicates that the level of Arabic vocabulary among the SMKA students in Malacca are at a moderate level (mean 3.1, SD 1.38).

Arabic is a foreign language offered in the secondary school especially in SMKAs. According to Teh \& Embi (2010), language status has an influence on language learning and cognitive development. This situation also affects the perception of students on Arabic, which is considered as a foreign language in school. Therefore, students are less concerned to learn new foreign words because they consider it difficult to understand and thus,

Table 5. Frequency, percentage, mean and standard deviation for arabic vocabulary learning strategies during the examination period (VLCE).

\begin{tabular}{|c|c|c|c|c|c|c|c|c|}
\hline Vocabulary Learning Strategies & $\begin{array}{l}\text { Strongly Not } \\
\text { Agree } \\
\text { (N) } \%\end{array}$ & $\begin{array}{c}\text { Do Not Agree } \\
\text { (N) } \%\end{array}$ & $\begin{array}{l}\text { Somewhat } \\
\text { Agree } \\
\text { (N) } \%\end{array}$ & $\begin{array}{l}\text { Agree } \\
\text { (N) \% }\end{array}$ & $\begin{array}{l}\text { Strongly } \\
\text { Agree } \\
\text { (N) } \%\end{array}$ & Mean & $\begin{array}{c}\text { Standard } \\
\text { Deviation }\end{array}$ & Interpretation \\
\hline $\begin{array}{c}\text { [D28] I memorize difficult Arabic } \\
\text { vocabulary for the purpose of ex- } \\
\text { amination. }\end{array}$ & $\begin{array}{l}(8) \\
5.1\end{array}$ & $\begin{array}{l}(23) \\
14.6\end{array}$ & $\begin{array}{l}(39) \\
24.8\end{array}$ & $\begin{array}{l}(61) \\
38.9\end{array}$ & $\begin{array}{l}(26) \\
16.6\end{array}$ & $3: 47$ & 1089 & Low \\
\hline $\begin{array}{l}\text { [D29] I talk to a friend about the } \\
\text { questions on Arabic vocabulary that } \\
\text { has come out in the examination. }\end{array}$ & $\begin{array}{l}(6) \\
3.8\end{array}$ & $\begin{array}{c}(12) \\
7.6\end{array}$ & $\begin{array}{l}(50) \\
31.8\end{array}$ & $\begin{array}{l}(59) \\
37.6\end{array}$ & $\begin{array}{l}(30) \\
19.1\end{array}$ & 3.61 & 1005 & Medium High \\
\hline $\begin{array}{l}\text { [D30] I do Arabic vocabulary } \\
\text { exercises that have come out in the } \\
\text { examination. }\end{array}$ & $\begin{array}{c}(13) \\
8.3\end{array}$ & $\begin{array}{l}(30) \\
19.1\end{array}$ & $\begin{array}{l}(47) \\
29.9\end{array}$ & $\begin{array}{l}(51) \\
32.5\end{array}$ & $\begin{array}{l}(16) \\
10.2\end{array}$ & 3.17 & 1110 & Low \\
\hline $\begin{array}{c}\text { [D31] I use variety of new Arabic } \\
\text { vocabulary to answer the exam } \\
\text { questions. }\end{array}$ & $\begin{array}{l}(16) \\
10.2\end{array}$ & $\begin{array}{l}(36) \\
22.9\end{array}$ & $\begin{array}{l}(68) \\
43.3\end{array}$ & $\begin{array}{l}(27) \\
17.2\end{array}$ & $\begin{array}{c}(10) \\
6.4\end{array}$ & 2.87 & $3: 04$ & Low \\
\hline $\begin{array}{l}\text { [D32] I check my vocabulary } \\
\text { answers before handed it in to the } \\
\text { teacher. }\end{array}$ & $\begin{array}{l}(21) \\
13.4\end{array}$ & $\begin{array}{l}(31) \\
19.7\end{array}$ & $\begin{array}{l}(45) \\
28.7\end{array}$ & $\begin{array}{l}(41) \\
26.1\end{array}$ & $\begin{array}{l}(19) \\
12.1\end{array}$ & $3: 04$ & 1219 & Low \\
\hline
\end{tabular}


they quickly forgot the new vocabulary learned.

These findings confirm the model of short-term memory and long-term memory by Macaro (2002). The vocabulary of a foreign language will disappear in a short time if the students do not use specific vocabulary learning strategies such as repetition and drills. According to Schmitt (2000), the repetition strategy will enhance long-term memory of a vocabulary. The students who use memorizing strategies are easier to master a lot of vocabulary (Hamzah, Kafipour, \& Abdullah, 2009). Based on the findings by Schmitt (2000), he stated that short-term memory could provide a good indicator for one's vocabulary achievement. However, his findings do not apply to SMKAs students in Melaka.

This quantitative study is a limited study in terms of respondents and focus of study. The survey study was conducted via questionnaires distributed to students at two selected National Religious Secondary School (SMKA), where Arabic has become a compulsory foreign language subject. In this study, the researchers only had to focus on Arabic Vocabulary Learning Strategies component without observing the language learning strategies of the language skills.

This study provides information about the level of Arabic Vocabulary Learning Strategies applied by National Religious Secondary School (SMKA) and their level of vocabulary mastery. Therefore, subsequent studies should be carried out to get more accurate information on the topic by involving a wide range of respondents nationwide. Other than that, more detailed research methods such as interviews and direct observations can give more detailed information.

\section{Conclusion}

The study finds that the level of Arabic Vocabulary Learning Strategies: VLSE, VLSO and VLCE used by the SMKAs students are at a moderate level. Among the factors that contribute to the low level of vocabulary mastery are the students who do not revise on the new vocabulary learned, do not do vocabulary exercises, do not record the new vocabulary learned and do not read and find the Arabic materials in the relevant media. The students' ability to memorize the vocabulary only happens in a short period of time and all these weaknesses affect the students' ability to master the Arabic language.

In conclusion, Arabic Vocabulary Learning Strategies need to be exposed to the students, so that they can store new information in relation with Arabic vocabulary in their long-term memory and can reproduce the words to be used when necessary. The teachers also need to disseminate information on vocabulary learning strategies directly or indirectly, so the students' achievements in their foreign language skills can be improved and enhanced.

\section{References}

Baharudin, H., \& Ismail, Z. (2014). Vocabulary Learning Strategies and Arabic Vocabulary Size among Pre-University Students in Malaysia. International Education Studies, 7, 219-226. http://doi.org/10.5539/ies.v7n13p219

Daud, N., \& Pisal, N. A. (2014). Permasalahan Pertuturan Dalam Bahasa Arab Sebagai Bahasa Kedua. Gema Online Journal of Language Studies, 14, 117-133. http://dx.doi.org/10.17576/GEMA-2014-1401-08

Embi, M. A., Long, J., \& Hamzah, M. I. (2001). Language Learning Strategies Employed by Secondary School Students in Malaysia. Jurnal Pendidikan (UKM), 26, 3-20. http://myais.fsktm.um.edu.my/2761/

Gan, Z. (2012). Understanding L2 Speaking Problems: Implications for ESL Curriculum Development in a Teacher Training Institution in Hong Kong. Australian Journal of Teacher Education, 37, 43-59. http://doi.org/10.14221/ajte.2012v37n1.4

Hamzah, M. S. G., Kafipour, R., \& Abdullah, S. K. (2009). Vocabulary Learning Strategies of Iranian Undergraduate EFL Students and Its Relation to Their Vocabulary Size. European Journal of Social Sciences, 11, 39-50.

Horwitz, E. K., \& Oxford, R. (1991). Language Learning Strategies: What Every Teacher Should Know. The Modern Language Journal, 75, 130. http://doi.org/10.2307/329849

Macaro, E. (2002). Learning Strategies in Foreign and Second Language Classrooms: The Role of Learner Strategies. Young. Bloomsbury Publishing.

Mahamod, Z., \& Embi, M. A. (2005). Penggunaan strategi pembelajaran bahasa untuk menguasai kemahiran membaca. Jurnal Teknologi, 42, 1-18.

Mahamod, Z., Embi, M. A., \& Yusoff, N. M. R. N. (2010). Strategi Pembelajaran Bahasa Melayu dan Inggeris Murid Cemerlang Inventori Strategi Belajar-Cara-Belajar-Bahasa. Bandung: Fakulti Pendidikan UKM.

Nurazan, M. R. (2004). Strategi pembelajaran bahasa dalam pembelajaran bahasa Arab di Kusza. Bangi: Universiti Ke- 
bangsaan Malaysia.

Schmitt, N. (2000). Vocabulary in Language Teaching. TESOL Quarterly, 36, 235. http://doi.org/10.2307/3588334

Susanti, R. (2002). Penguasaan Kosa Kata dan Kemampuan Membaca Bahasa Inggeris. Jurnal Pendidikan Penabur, 1, 8793.

Teh, K. S. M., \& Embi, M. A. (2010). Strategi Pembelajaran Bahasa. Kuala Lumpur: Penerbit Universiti Malaya.

Teh, K. S. M., Yusoff, N. M. R. N., Embi, M. A., \& Mahamod, Z. (2000). Hubungan Penggunaan Strategi Pembelajaran Bahasa dengan Tahap Penguasaan Bahasa Arab. Journal of Islamic and Arabic Education, 1, 41-56.

Yasim, I. M. M. (2012). Hubungan strategi pembelajaran kosa kata dengan tahap penguasaan kosa kata murid. Bangi: Universiti Kebangsaan Malaysia.

Yusoff, N. M. R. N., Ghani, K. A., \& Al-Qusyairi, M. (2008). Fan tadris al-lughah al-arabiyah li ghair al-arab. Bandung: Fakulti Pendidikan UKM. 